\title{
PENGARUH KUALITAS PELAYANAN TERHADAP KEPUASAN PELANGGAN DAN DAMPAKNYA TERHADAP LOYALITAS PELANGGAN
}

\author{
Sri Rahayu ${ }^{1}$, Lela Nurlaela Wati ${ }^{2}$ \\ ${ }^{1}$ STIE Muhammadiyah Jakarta, ayu041992@yahoo.co.id \\ ${ }^{2}$ STIE Muhammadiyah Jakarta, lela@ stiemj.ac.id
}

\begin{abstract}
ABSTRAK
Penelitian ini bertujuan untuk menganalisis bukti empiris pengaruh kualitas pelayanan terhadap kepuasan pelanggan dan dampaknya terhadap loyalitas pelanggan pada PT Indovisual Service Solution Jakarta. Sample dalam penelitian ini sebanyak 124 pelanggan, teknik pengambilan sample probability sampling, yakni teknik pengambilan sampel yang memberikan peluang yang sama bagi setiap unsur (anggota) populasi untuk dipilih menjadi anggota sampel. Analisis data yang digunakan adalah Structural Equation Modeling (SEM). hasil penelitian secara empiris Kualitas pelayanan berpengaruh positif dan signifikan terhadap kepuasan pelanggan. Hasil ini menunjukkan bahwa dengan meningkatkan kualitas pelayanan maka pelanggan akan merasa puas dengan pelayanan yang diberikan. Kualitas Pelayanan berpengaruh positif dan signifikan terhadap loyalitas Pelanggan. Hasil ini menunjukkan bahwa dengan meningkatkan kualitas pelayanan maka pelanggan akan merasa loyal dan akan terus menggunakan jasa PT Indovisual Service Solution Kepuasan pelanggan tidak berpengaruh positif signifikan terhadap loyalitas pelanggan. Artinya adalah semakin rendah kepuasan pelanggan maka loyalitas pelanggan juga akan semakin menurun Kualitas Pelayanan berpengaruh positif dan signifikan terhadap loyalitas Pelanggan. Hasil ini menunjukkan bahwa dengan meningkatkan kualitas pelayanan maka pelanggan akan merasa loyal dan akan terus menggunakan jasa PT Indovisual Service Solution.
\end{abstract}

Kata Kunci: kualitas pelayanan, kepuasan pelanggan dan loyalitas pelanggan

\begin{abstract}
This study aims to analyze empirical evidence of the effect of service quality on customer satisfaction and its impact on customer loyalty at PT Indovisual Service Solution Jakarta. Samples in this study were 124 customers, probability sampling techniques, namely sampling techniques that provide equal opportunities for each element (member) of the population to be selected as sample members. Analysis of the data used is Structural Equation Modeling (SEM). empirical research results Service quality has a positive and significant effect on customer satisfaction. These results indicate that by improving the quality of service, customers will feel satisfied with the services provided. Service Quality has a positive and significant effect on customer loyalty. These results indicate that by improving the quality of service, customers will feel loyal and will continue to use the services of PT Indovisual Service Solution. Customer satisfaction does not have a significant positive effect on customer loyalty. This means that the lower the customer satisfaction, customer loyalty will also decrease the quality of service has a positive and significant effect on customer loyalty. These results indicate that by improving the quality of service, customers will feel loyal and will continue to use the services of PT Indovisual Service Solution.
\end{abstract}

Keywords: service quality, customer satisfaction and customer loyalty 


\section{PENDAHULUAN}

Seiring perkembangan perusahaan, pelayanan tentu juga harus ditingkatkan. Kualitas pelayanan merupakan kesan utama yang diterima oleh konsumen, hal itu juga yang mempengaruhi kepuasan pada konsumen sehingga berkeinginan untuk menggunakan jasa pada perusahaan yang sama dikemudian hari. Pada situasi seperti ini perusahaan mendapatkan keuntungan lebih maksimal karena loyalitas pelanggan sudah terbentuk. Hubungan baik inilah yang harus terus dijaga oleh perusahaan untuk mempertahankan pelanggan.

Fakta yang terjadi adalah pelanggan yang mengkonsumsi dan menikmati pelayanan yang diberikan perusahaan, sehingga pelangganlah yang bisa menilai kualitas pelayanan. Hal ini berarti kualitas pelayanan yang baik bukan dilihat dari sudut pandang perusahaan, namun didasarkan pada sudut pandang pelanggan. Oleh karena itu perusahaan perlu untuk meningkatkan kepuasan pelanggan dan sangat penting untuk mengaplikasikan lima dimensi kualitas pelayanan yang dijadikan konsumen sebagai indikator dalam menilai apakah jasa yang diberikan perusahaan tersebut berkualitas atau tidak. Parasuraman dkk dalam Lupiyoadi (2013) mengungkapkan kelima dimensi tersebut adalah "tangible, reability, responsiveness, assurance, dan emphaty". Kelima dimensi kualitas pelayanan tersebut harus ditunjukkan dan dibuktikan oleh perusahaan agar memberikan kesan kepada pelanggan pada saat memberikan pelayanan, karena dengan cara inilah kepercayaan pelanggan terhadap perusahaan dapat tercipta sehingga pelanggan merasa puas terhadap pelayanan yang diberikan oleh perusahaan. Pelayanan yang baik mendorong minat pelanggan untuk menggunakan kembali jasa tersebut sehingga tercipta loyalitas.

Loyalitas konsumen juga dapat terbentuk dari kepuasan yang dirasakan oleh konsumen. Kotler dan Keller (2009), menyatakan bahwa kepuasan adalah perasaan senang atau kecewa seseorang yang muncul setelah membandingan kinerja (atau hasil) produk yang dipikirkan terhadap kinerja (atau hasil) yang diharapkan. Dengan kata lain, seseorang merasa puas apabila hasil yang didapat minimal mampu memenuhi harapannya sedangkan seseorang merasa tidak puas apabila hasil yang didapat tidak mampu memenuhi harapannya. Kepuasan yang dirasakan seseorang akan memberikan dampak terhadap perilaku penggunaan kembali secara terus menerus sehingga terbentuklah loyalitas.

Penelitian ini dilakukan di PT. Indovisual Service Solution Komplek perkantoran Multiguna blok 6 SR. Jalan Rajawali Selatan Raya Jakarta yang merupakan salah satu perusahaan yang bergerak di bidang penyedia jasa service, suku cadang, lampu dan aksesoris Multimedia projector. Salah satu pelayanan yang disediakan PT Indovisual Service Solution kepada konsumen adalah penampilan karyawan sangat menarik serta lokasi yang ditempati strategis (tangible), memberikan pelayanan yang cepat dan selalu memenuhi janji (reability), ketepatan dalam pelayanan dan kesigapan membantu pelanggan (responsiveness), kemampuan karyawan dalam menyampaikan informasi, reputasi pelayanan yang sudah cukup dikenal baik dan sopan santun karyawan (assurance), hubungan karyawan dengan konsumen cukup baik, karyawan menjalin komunikasi kepada setiap konsumen serta karyawan mempunyai perhatian dan selalu memahami keinginan konsumen (emphaty)

Namun demikian, saat ini jumlah konsumen yang melakukan pembelian sparepart dan lampu projector mengalami penurunan. Berikut adalah adalah data mengenai konsumen pada PT. Indovisual Servicesolution periode Januari-Maret 2018 : 
Tabel 1.

Jumlah Penjualan Part dan Lampu Projector PT.Indovisual Service Solution

Bulan Januari-Maret 2018

\begin{tabular}{|l|c|c|}
\hline \multicolumn{1}{|c|}{ Bulan } & $\begin{array}{l}\text { Jumlah } \\
\text { Konsumen }\end{array}$ & $\begin{array}{l}\text { Peningkatan/ } \\
\text { Penurunan }\end{array}$ \\
\hline Januari & 41 & - \\
\hline Februari & 44 & 3 \\
\hline Maret & 39 & -5 \\
\hline Jumlah & 124 & -2 \\
\hline
\end{tabular}

Sumber : PT.Indovisual Service Solution

Tabel 1 menunjukkan bahwa pada konsumen PT. Indovisual Service Solution cenderung menurun. Secara keseluruhan, konsumen dealer PT. Indovisual Service Solution mengalami penurunan penjualan sparepart dan lampu rata-rata sebesar 2 orang. Adanya penurunan tersebut disebabkan oleh banyak faktor, diantaranya adalah banyak didirikan perusahaan perusahaan pesaing dengan lokasi yang hampir berdekatan, sehingga memberikan alternatif pilihan bagi konsumen untuk melakukan service selain di PT Indovisua. Service Solution yang kemungkinan memberikan pelayanan yang lebih baik, kualitas pelayanan yang kurang memuaskan, harga yang cenderung lebih mahal dibandingkan dengan service center yang lain, dan respon yang lambat untuk pemberian informasi harga, estimasi indent sparepart dan lampu yang terlalu lama juga mempengaruhi menurunnya penjualan.

Hasil penelitian terdahulu mengenai Kualitas pelayanan terhadap kepuasan pelanggan memberikan bukti yang beragam, dimana sebagian peneliti menghasilkan bahwa kualitas pelayanan berpengaruh terhadap kepuasan pelanggan. Pengaruh positif kualitas pelayanan terhadap kepuasan pelanggan di dokumentasikan oleh Jahanshahi (2011), Asfaw (2015), Alotaibi (2015), Hafeez (2012), Nandhasari (2015), Atsalada (2012), Safitri (2014), Normasari (2013), Mayasari (2013), Ramadhan (2013), Yuliarmi, Riyasa (2007), Sinaga (2010),

Begitu juga dengan hasil penelitian terdahulu mengenai Kualitas pelayanan terhadap loyalitas pelanggan. Pengaruh positif kualitas pelayanan terhadap loyalitas pelanggan di dokumentasikan oleh Nandhasari (2015). Namun beberapa peneliti menghasilkan pengaruh negative kualitas pelayanan terhadap loyalitas pelanggan yang di dokumentasikan oleh Normasari (2013), Hasil penelitian terdahulu mengenai kepuasan pelanggan berpengaruh terhadap loyalitas pelanggan. Sebagian peneliti menghasilkan pengaruh positif kepuasan pelanggan berpengaruh terhadap loyalitas yang di dokumentasikan oleh Jahanshahi (2011), Asfaw (2015), Alotaibi (2015), Hafeez (2012), Nandhasari (2015), Atsalada (2012), Safitri (2014), Normasari (2013), Mayasari (2013), Harun (2006), Ramadhan (2013), Sinaga (2010), Namun menghasilkan penelitian bahwa pengaruh kepuasan pelanggan terhadap loyalitas pelanggan tidak berpengaruh positif signifikan Kemudian hasil penelitian terdahulu mengenai kualitas pelayanan berpengaruh terhadap loyalitas pelanggan melalui kepuasan pelanggan di dokumentasikan oleh Safitri (2014), Berdasarkan uraian latar belakang tujuan penelitian ini adalah pengaruh kualitas pelayanan terhadap kepuasan pelanggan dan dampaknya terhadap loyalitas pelanggan. Penelitian ini 
berbeda dengan penelitian sebelumya karena menguji secara langsung maupun tidak langsung melalui kepuasan pelanggan pada PT indovisual service solution Jakarta.

\section{KAJIAN LITERATUR \\ Kualitas pelayanan jasa}

Menurut Kotler dan Keller (2012) layanan (service) adalah semua tindakan atau kinerja yang dapat ditawarkan satu pihak kepada pihak lain yang pada intinya tidak berwujud dan tidak menghasilkan kepemilikan apapun. Menurut Parasuraman dalam Lupiyoadi (2013:216), kualitas jasa dapat didefiniskan sebagai sebarapa jauh perbedaan antara kenyataan dan harapan pelanggan atas layanan yang mereka terima. kualitas jasa merupakan upaya pemenuhan kebutuhan dan keinginan konsumen guna mencapai tingkat keunggulan dari apa yang diharapkan oleh konsumen, dengan kata lain kualitas jasa berpusat pada upaya-upaya layanan apa saja yang akan dilakukan oleh produsen (pihak pemberi jasa) dengan tujuan agar para konsumen merasa puas akan layanan yang diterimanya. Menurut Parasuraman dkk dalam Lupiyoadi (2013:216-217), terdapat lima (5) dimensi kualitas pelayanan jasa (service quality) yaitu berwujud (tangible), kehandalan (reliability), daya tanggap (responsiveness), jaminan dan kepastian (assurance) dan empati (empathy)

\section{Kepuasan Pelanggan}

Menurut Kotler dan Keller (2009:138) satisfaction atau kepuasan adalah perasaan senang atau kekecewaan seseorang yang dihasilkan dari membandingkan kinerja produk yang dirasakan (atau hasil) dengan ekspetasi yang diharapkan. Jika kinerja jauh dari harapannya, maka konsumen tidak puas. Jika kinerja sesuai dengan harapan, makan konsumen akan puas. Jika kinerja melebihi harapan, pelanggan yang sangat puas atau senang. Berdasarkan studi literature dan pengalaman menjadi konsultan beberbagai perusahaan di Indonesia, menurut Irawan (2009:37-39) berpendapat ada 5 (lima) driver utama kepuasan konsumen adalah kualitas produk, harga, kualitas pelayanan (service quality), faktor emosional (emotional factor) dan kemudahan.

\section{Loyalitas Pelanggan}

Kotler dan Keller (2012) menyatakan bahwa loyalitas pelanggan merupakan situasi yang pelanggan secara konsisten membelanjakan seluruh anggaran yang ada untuk membeli produk suatu layanan jasa dari penjual yang sama. Loyalitas konsumen terjadi dalam beberapa fase.

\section{Pengembangan Hipotesis}

Kualitas pelayanan yang maksimal diharapkan akan menciptakan suatu kepuasan pada diri konsumen. Menurut Kotler dan Keller (2012) layanan (service) adalah semua tindakan atau kinerja yang dapat ditawarkan satu pihak kepada pihak lain yang pada intinya tidak berwujud dan tidak menghasilkan kepemilikan apapun. Kotler dan Keller (2012) mengemukakan bahwa kepuasan pelanggan merupakan tingkat perasaan pelanggan setelah membandingkan kinerja layanan yang dirasakan dibanding dengan harapan. Seorang pelanggan yang puas adalah pelanggan yang merasa mendapatkan value dari produsen atau penyedia jasa. Value ini bisa berasal dari produk, pelayanan, sistem atau sesuatu yang bersifatemosional. Value bagi pelanggan ini dapat diciptakan melalui atribut-atribut pemasaran perusahaan yang dapat menjadi unsur-unsur stimulasi bagi perusahaan untuk mempengaruhi konsumen dalam pembelian. Jika pembelian yang dilakukan mampu memenuhi kebutuhan dan keinginannya atau mampu memberikan kepuasan, terjadi pembelian ulang pada masa depan Paliliati (2007). Kepusan tercipta dari kualitas pelayanan yang baik. Menurut Parasuraman dkk dalam Lupiyoadi (2013), kualitas jasa dapat didefiniskan sebagai sebarapa jauh perbedaan antara kenyataan dan harapan pelanggan atas layanan yang mereka terima. kualitas pelayanan merupakan upaya pemenuhan 
kebutuhan dan keinginan konsumen guna mencapai tingkat keunggulan dari apa yang diharapkan oleh konsumen, dengan kata lain kualitas pelayanan berpusat pada upaya-upaya layanan apa saja yang akan dilakukan oleh produsen (pihak pemberi jasa) dengan tujuan agar para konsumen merasa puas akan layanan yang diterimanya. Harapan para konsumen ini didasarkan pada informasi yang diterimanya baik itu dari mulut ke mulut, kebutuhan pribadi, pengalaman di masa lampau, dan komunikasi eksternal (iklan dan berbagai bentuk promosi perusahaan lainnya).

Hasil penelitian terdahulu mengenai Kualitas pelayanan terhadap kepuasan pelanggan memberikan bukti yang beragam, dimana sebagian peneliti menghasilkan bahwa kualitas pelayanan berpengaruh terhadap kepuasan pelanggan. Pengaruh positif kualitas pelayanan terhadap kepuasan pelanggan di dokumentasikan oleh Jahanshahi (2011), Asfaw (2015), Alotaibi (2015), Hafeez (2012), Nandhasari (2015), Atsalada (2012), Safitri (2014), Normasari (2013), Mayasari (2013), Ramadhan (2013), Yuliarmi, Riyasa (2007), Sinaga (2010). Berdasarkan uraian di atas, maka hipotesis yang diajukan dalam penelitian ini adalah:

\section{H1 : Terdapat pengaruh positif kualitas pelayanan terhadap kepuasan pelanggan}

Konsumen yang loyal terhadap suatu barang atau jasa tertentu disebabkan oleh kualitas pelayanan yang baik dan memuaskan. Jika kualitas pelayanan yang diberikan baik dan memuaskan serta dapat memberikan keuntungan yang maksimal bagi konsumennya maka konsumen pun akan merasa loyal dan akan memberikan sikap yang positif terhadap produsen (penyedia jasa) tersebut secara konsisten. Menurut Kotler dan Armstrong (2009:13), konsumen yang telah loyal pada suatu produk atau jasa dapat diartikan konsumen tersebut merasa terpuaskan kebutuhannya sehingga konsumen tersebut akan kembali membeli, tidak akan berganti pada produk atau jasa lain dan mereka akan memberi tahu yang lain tentang pengalaman baik mereka dengan produk atau jasa tersebut. Kualitas adalah sebuah kata yang bagi penyedia jasa merupakan sesuatu yang harus dikerjakan dengan baik. Dalam menentukan kualitas jasa, terdapat lima dimensi kualitas jasa sebagaimana telah dikemukakan oleh Parasuraman dalam Lupiyoadi (2013) yaitu dimensi tangibles, reliability, responsiveness, assurance dan emphaty. Kualitas layanan yang maksimal diharapkan akan tercipta suatu kepuasan pada diri konsumen. Begitu juga dengan hasil peneltiain terdahulu mengenai Kualitas pelayanan terhadap loyalitas pelanggan. Pengaruh positif kualitas pelayanan terhadap loyalitas pelanggan di dokumentasikan oleh Nandhasari (2015). Berdasarkan uraian di atas, maka hipotesis yang diajukan dalam penelitian ini adalah

\section{H2 : Terdapat Pengaruh Positif Kualitas Layanan Terhadap Loyalitas Pelanggan}

Menurut Kotler dan Keller (2009:138) satisfaction atau kepuasan adalah perasaan senang atau kekecewaan seseorang yang dihasilkan dari membandingkan kinerja produk yang dirasakan (atau hasil) dengan ekspetasi yang diharapkan. Jika kinerja jauh dari harapannya, maka konsumen tidak puas. Jika kinerja sesuai dengan harapan, makan konsumen akan puas. Jika kinerja melebihi harapan, pelanggan yang sangat puas atau senang

Menurut Hasan (2014:90), kepuasan atau ketidakpuasan merupakan respons konsumen terhadap evaluasi ketidakpuasan yang dipersepsikan antara harapan sebelum pembelian dari kinerja aktual produk/jasa yang dirasakan setelah pemakaiannya.

Berdasarkan beberapa definisi dapat disimpulkan bahwa kepuasan konsumen merupakan respons yang ditunjukkan oleh konsumen terhadap pelayanan atau kinerja (hasil) yang diterima, kemudian konsumen akan membandingkan kinerja (hasil) dengan harapan yang diinginkanya. Apabila kinerja (hasil) yang diterima lebih dari harapan maka konsumen tersebut merasa puas, begitu pula sebaliknya apabila kinerja (hasil) yang diterimanya tidak memenuhi atau sama dengan harapannya maka dapat dikatakan konsumen merasa tidak puas akan kinerja (hasil) yang diterima. 
Kepuasan konsumen ini merupakan modal dasar bagi perusahaan dalam membentuk loyalitas konsumen, dimana konsumen yang loyal adalah merupakan asset yang paling berharga bagi perusahaan dalam meningkatkan profitabilitas perusahaan

Dari kedua pendapat di atas, dapat dikatakan bahwa kepuasan konsumen mempunyai pengaruh positif terhadap loyalitas. Seorang konsumen yang merasa puas dan harapannya terpenuhi setelah menggunakan jasa akan kembali menggunakan jasa tersebut di kemudian hari.

1. Memberikan reward, hanya transaksi yang membawahasil yang mendapatkan poin reward(reward the right result)

2. Akan untuk selalu mendengarkan kebutuhan dan keinginan pelanggan, kemudianberhatihati ketika menjanjikan sesuatu (listen hard,talk straight).

3. Komunikasikan dulu manfaat kepada pelanggan sebelum mengajaknya bergabung Preach what you practice).

Kemudian hasil penelitian terdahulu mengenai kepuasan pelanggan berpengaruh terhadap loyalitas pelanggan. Sebagian peneliti menghasilkan pengaruh positif kepuasan pelanggan berpengaruh terhadap loyalitas yang di dokumentasikan oleh Jahanshahi (2011), Asfaw (2015), Alotaibi (2015), Hafeez (2012), Nandhasari (2015), Atsalada (2012), Safitri (2014), Normasari (2013), Mayasari (2013), , Harun (2006), Ramadhan (2013), Sinaga (2010),

Berdasarkan uraian di atas, maka hipotesis yang diajukan dalam penelitian ini adalah :

\section{$\mathrm{H}_{3}$ : Terdapat Pengaruh Positif Kepuasan Pelanggan Terhadap Loyalitas}

Konsumen yang setia pada produsen atau perusahaan tertentu untuk selamanya. Menurut Kotler dan Armstrong (2009:13), konsumen yang telah loyal pada suatu produk atau jasa dapat diartikan konsumen tersebut merasa terpuaskan kebutuhannya sehingga konsumen tersebut akan kembali membeli, tidak akan berganti pada produk atau jasa lain dan mereka akan memberi tahu yang lain tentang pengalaman baik mereka dengan produk atau jasa tersebut. Dalam menentukan kualitas jasa, terdapat lima dimensi kualitas jasa sebagaimana telah dikemukakan oleh Parasuraman dalam Lupiyoadi (2013) yaitu dimensi tangibles, reliability, responsiveness, assurance dan emphaty. Kualitas layanan yang maksimal diharapkan akan tercipta suatu kepuasan pada diri konsumen. Sedangkan menurut Kotler dalam Lupiyoadi (2013:228), kepuasan merupakan tingkat perasaan dimana seseorang menyatakan hasil perbandingan atas kinerja produk (jasa) yang diterima dan yang diharapkan. Seorang pelanggan yang puas adalah pelanggan yang merasa mendapatkan value dariprodusen atau penyedia jasa. Value ini bisa berasal dari produk, pelayanan, sistem atau sesuatu yang bersifatemosional. Value bagi pelanggan ini dapat diciptakan melalui atribut-atribut pemasaran perusahaan yang dapat menjadi unsur-unsur stimulasi bagi perusahaan untuk mempengaruhi konsumen dalam pembelian. Jika pembelian yang dilakukan mampu memenuhi kebutuhan dan keinginannya atau mampu memberikan kepuasan, terjadi pembelian ulang pada masa depan (Paliliati, 2007).

Pengaruh positif kualitas pelayanan terhadap kepuasan pelanggan di dokumentasikan oleh Jahanshahi (2011), Asfaw (2015), Alotaibi (2015), Hafeez (2012), Nandhasari (2015), Atsalada (2012), Safitri (2014), Normasari (2013), Mayasari (2013), Ramadhan (2013), Yuliarmi, Riyasa (2007), Sinaga (2010). Pengaruh positif kualitas pelayanan terhadap loyalitas pelanggan di dokumentasikan oleh Safitri (2014), Huan Huu (2016). Semakin baik kualitas pelayanan akan meningkatkan kepuasan pelanggan dan ketika kepuasan pelanggan meningkat makan loyalitas pelangganpun akan meningkat. Berdasarkan uraian diatas maka hipotesis yang diajukan dalam penelitian ini adalah :

H4 : Terdapat pengaruh positif kualitas pelayanan terhadap loyalitas pelanggan melalui kepuasan pelanggan 
Berdasarkan teori dan penelitian terdahulu yang dijelaskan di atas, maka penulis membuat kerangka pikir mengenai pengaruh gaya kepemimpinan terhadap disiplin kerja dan dampaknya terhadap kinerja karyawan sebagai berikut:

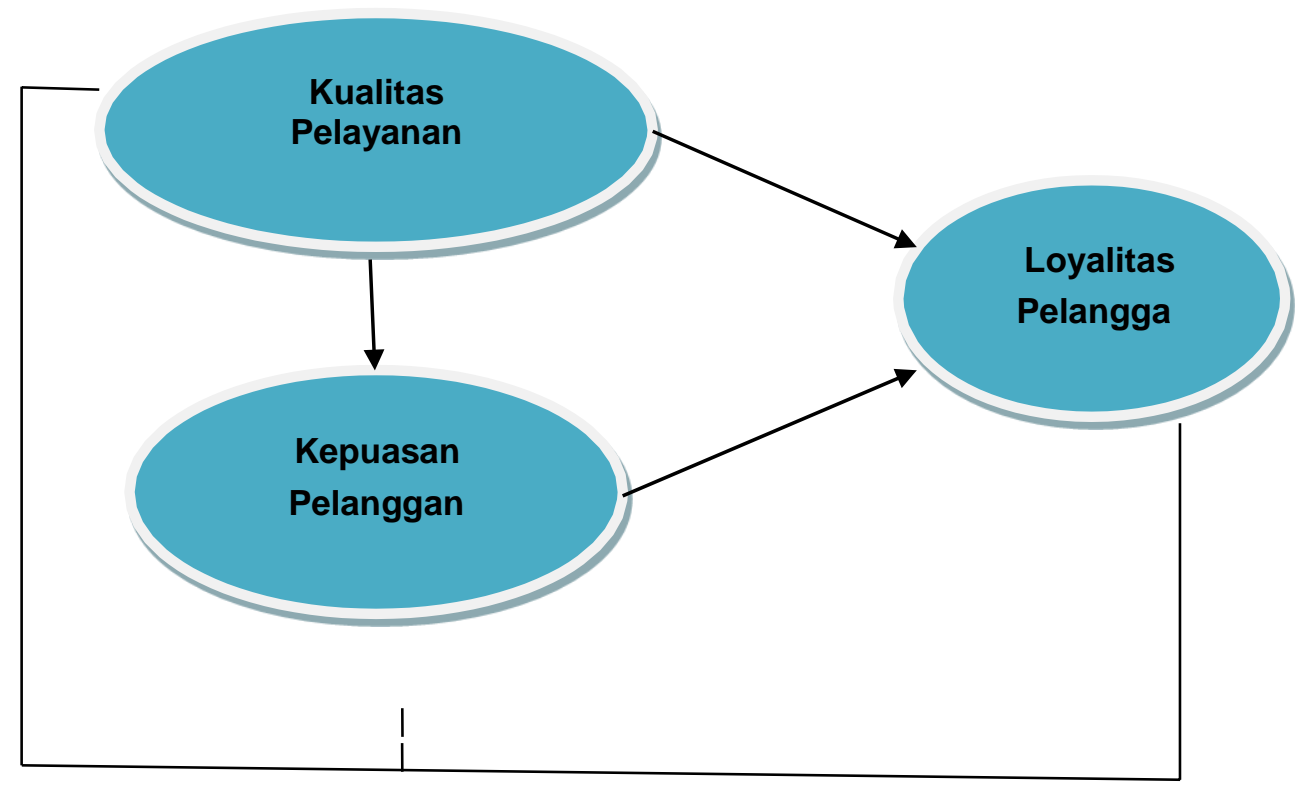

Gambar 1. Kerangka Pikir

\section{METODE PENELITIAN}

Sampel dalam penelitian ini PT Indovisual Service Solution Jakarta sebanyak 124 pelanggan Berikut ini adalah variable, dimensi dan indicator yang digunakan dalam penelitian ini:

Tabel 2. Operasional Variabel

\begin{tabular}{|c|c|c|c|}
\hline Variabel & KonsepVariabel & Dimensi & Indikator \\
\hline \multirow[t]{2}{*}{$\begin{array}{l}\text { Kualitas } \\
\text { Pelayanan } \\
\text { (X) } \\
\text { Independent } \\
\text { Variabel }\end{array}$} & \multirow[t]{2}{*}{$\begin{array}{l}\text { Kualitas pelayanan Merupakan } \\
\text { tingkat keunggulan yang } \\
\text { diharapkan dan pengendalian } \\
\text { atas tingkat keunggulan } \\
\text { tersebut untuk memenuhi } \\
\text { keinginan pelanggan. }\end{array}$} & $\begin{array}{l}\text { 1. Tangibles } \\
\text { (WujudFisik) }\end{array}$ & $\begin{array}{ll}\text { 1) } & \text { Kebersihan kantor } \\
\text { 2) } & \text { AC ruangan dapat } \\
\text { digunakan. } \\
\text { 3) } \\
\text { 4enampilan karyawan } \\
\text { Ruang tunggu dan fasilitas } \\
\text { memadai }\end{array}$ \\
\hline & & $\begin{array}{l}\text { 2.Reability } \\
\text { (Kehandalan) }\end{array}$ & $\begin{array}{ll}\text { 1) } & \text { Ketepatan waktu } \\
\text { 2) } & \text { Kehandalan } \\
\text { 3) } & \text { Kesiapan karyawan }\end{array}$ \\
\hline
\end{tabular}




\begin{tabular}{|c|c|c|c|}
\hline & & $\begin{array}{l}\text { 3.Responsivenes } \\
\text { (DayaTanggap) }\end{array}$ & $\begin{array}{l}\text { 1) Ketanggapan karyawan } \\
\text { terhadap permasalahan } \\
\text { pelanggan } \\
\text { 2) Dapat memberikan pelayanan } \\
\text { dengan cepat } \\
\text { 3) Dapat memberikan pelayanan } \\
\text { dengan sigap } \\
\text { 4) Kesediaan karyawan dalam } \\
\text { menanggapi sumbang saran } \\
\text { dari pelanggan }\end{array}$ \\
\hline & & $\begin{array}{l}\text { 4.Assurance } \\
\text { (Jaminan) }\end{array}$ & $\begin{array}{ll}\text { 1) } & \text { Memberikan rasa aman dan } \\
\text { nyaman kepada pelanggan. } \\
\text { 2) Keramahan karyawan } \\
\text { dalam memberi penjelasan } \\
\text { kepada pelanggan } \\
\text { 3) Kemampuan dan } \\
\text { pengetahuan karyaawan } \\
\text { 4) } \text { sopan santun yang dimiliki } \\
\text { karyawan terhadap } \\
\text { pelanggan }\end{array}$ \\
\hline & & $\begin{array}{l}\text { 5.Emphaty } \\
\text { (Empati) }\end{array}$ & $\begin{array}{l}\text { 1) } \begin{array}{l}\text { kemudahan bagi pelanggan } \\
\text { menghubungi perusahaan }\end{array} \\
\text { 2) Kemudahan dalam } \\
\text { transaksi } \\
\text { 3) } \\
\text { Perhatian karyawan } \\
\text { terhadap pelanggan tanpa } \\
\text { pilih pilih }\end{array}$ \\
\hline $\begin{array}{l}\text { Kepuasan } \\
\text { Pelanggan } \\
\text { (Y) } \\
\text { Dependent } \\
\text { Variabel }\end{array}$ & $\begin{array}{l}\text { Kepuasan nasabah Adalah } \\
\text { tingkat Perasaan senang } \\
\text { Atau kecewa }\end{array}$ & $\begin{array}{l}\text { 1) } \begin{array}{l}\text { Kesesuaian } \\
\text { dengan har }\end{array} \\
\text { 2) Kualitas } \\
\text { pelayanan } \\
\text { memasukar } \\
\text { 3) } \begin{array}{l}\text { Tingkat } \\
\text { kepuasan a } \\
\text { perusahaan }\end{array}\end{array}$ & $\begin{array}{l}\text { alitas pelayanan yang diberikan } \\
\text { n dari pelanggan. } \\
\text { g diberikan pada saat awal } \\
\text { it projector sampai selesai repair. } \\
\text { ila dibandingkan dengan } \\
\text { n yang sejenis. }\end{array}$ \\
\hline $\begin{array}{l}\text { Loyalitas } \\
\text { Pelanggan } \\
\text { (Z) } \\
\text { Dependent } \\
\text { Variabel }\end{array}$ & $\begin{array}{l}\text { Loyalitas merupakan aspek } \\
\text { kesukaan atau kecintaan } \\
\text { terhadap sebuah produk } \\
\text { sehingga pelanggan setia untuk } \\
\text { menggunakan atau memakainya }\end{array}$ & $\begin{array}{ll}\text { 1) } & \begin{array}{l}\text { Pelanggan } \\
\text { menjadikan } \\
\text { pilihan utar }\end{array} \\
\text { 2) } & \begin{array}{l}\text { Pelanggan } \\
\text { nggunakan }\end{array} \\
\text { service di I } \\
\text { 3) Pelanggan } \\
\text { untuk mela } \\
\text { Solution } \\
\text { 4) Pelanggan } \\
\text { mengenai I } \\
\text { orang lain } \\
\text { 5ika kemud } \\
\text { service lain } \\
\text { menggunak }\end{array}$ & $\begin{array}{l}\text { dovisual Sevice solution sebagai } \\
\text { dalam menggunakan jasa service } \\
\text { p setia berlangganan/me } \\
\text { a } \\
\text { visual Service Solution } \\
\text { ekomendasik an kemasyarakat } \\
\text { an service di Indovisual Service } \\
\text { gatakan halhal yang baik / positif } \\
\text { visual Service Solution kepada } \\
\text { hari pelanggan menggunakan jasa } \\
\text { sar kemungkinan pelanggan akan } \\
\text { kembali jasa service di Indovisual }\end{array}$ \\
\hline
\end{tabular}




\begin{tabular}{|l|l|l|}
\hline & 6) $\begin{array}{l}\text { Service Solution } \\
\text { Pelanggan lebih sering menggunakan jasa } \\
\text { service proyektor di Indovisual Service Projector } \\
\end{array}$ \\
\hline
\end{tabular}

Sumber : Data diolah

Penelitian ini menggunakan pendekatan Secondorder Confirmatory. Secondorder konstruk laten kualitas pelayanan diukur dengan 5 First Order komponen yaitu Tangibles, Reability,Responsiveness, Empaty and Assurance. Komponen Tangibles diukur oleh indikator X1.1.1-X1.1.5, Reability diukur oleh indikator X2.1.1 -X2.1.5, Responsiveness diukur oleh indikator X3.1.1 - X3.1.4,Empaty diukur oleh indikator X.5.1.1 - X5.1.4. dan Assurance diukur oleh indikator X4.1.1 - X4.1.5. Konstruk laten kepuasan nasabah diukur oleh indikator Y1.1 - Y1.5. . Konstruk laten loyalitas pelanggan diukur oleh indikator Z1.1-Z1.6.

Dalam pendekatan repeated indicators, ukuran indikator X1.1.1-Y2.5 digunakan dua kali, dimana pertama diukur oleh First Order Confirmatory dan kedua untuk mengukur Second Order Confirmatory (Wati, 2018).

Berikut ini adalah gambar Full Structural Equetion Modelling penelitian ini:

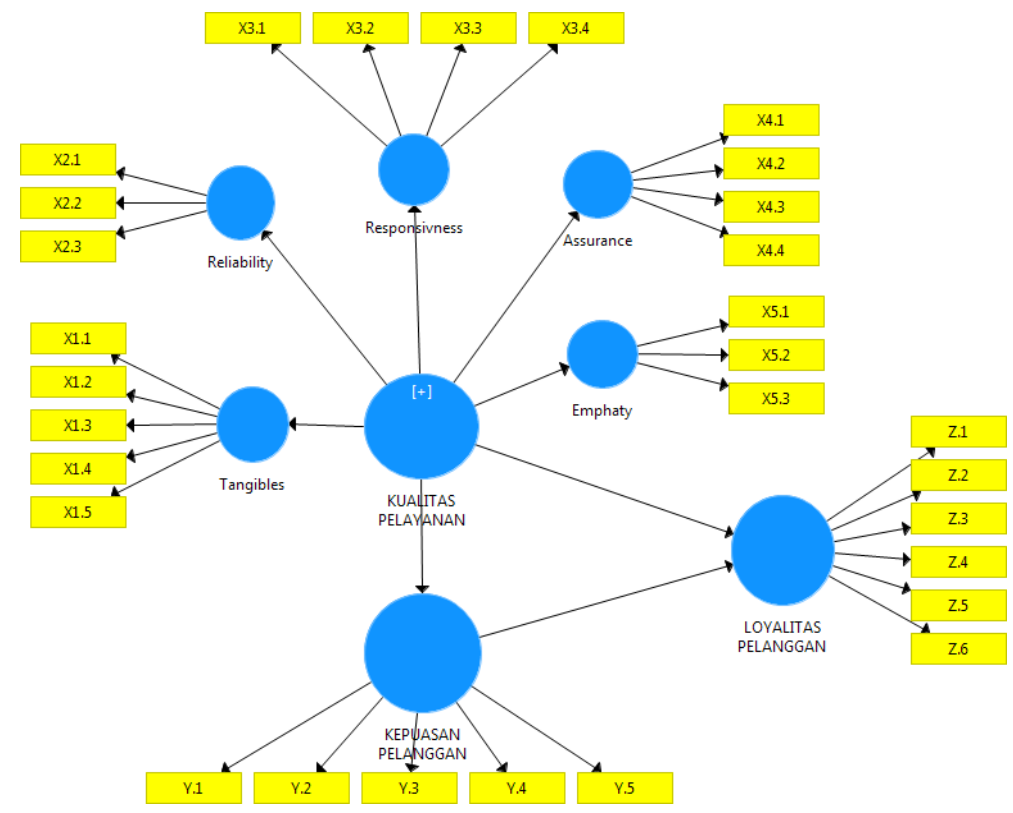

\section{Gambar 2. Model SEM}

Berdasarkan gambar model penelitian di atas, kemudian diterjemahkan ke dalam bentuk persamaan sebagai berikut :

$\mathrm{KPG}=\mathrm{a}+\mathrm{b} \mathrm{KP}+\mathrm{e}_{1}$

$\mathrm{LP}=\mathrm{a}+\mathrm{b}_{1} \mathrm{KP}+\mathrm{b}_{2} \mathrm{KPG}+\mathrm{b}_{4} \mathrm{KPKPG} \mathrm{e}_{2}$

Keterangan :

$\mathrm{KP}=$ Kualitas Pelayanan

$\mathrm{KPG}=$ Kepuasan Pelanggan

LP $=$ Loyalitas Pelanggan

$\mathrm{e}_{1}=$ Eror

$\mathrm{e}_{2}$ : Eror 


\section{PEMBAHASAN}

\section{Analisis Deskripsi}

Pada tahapan ini akan dilakukan analisis terhadap variabel-variabel penelitian berdasarkan item pertanyaan dalam kuesioner. Deskripsi dari variable-variabel penelitian tersebut dijelaskan pada tabel 4.1 sebagai berikut :

Tabel 3. Deskripsi Penelitian

\begin{tabular}{|c|c|c|c|c|c|c|c|c|c|c|c|}
\hline \multirow[t]{2}{*}{ Variabel\&Indikator } & \multicolumn{2}{|l|}{1} & \multicolumn{2}{|l|}{2} & \multicolumn{2}{|c|}{3} & \multicolumn{2}{|l|}{4} & \multicolumn{2}{|l|}{5} & \multirow[b]{2}{*}{ Mean } \\
\hline & $\mathbf{F}$ & $\%$ & $\mathbf{F}$ & $\%$ & $\mathbf{F}$ & $\%$ & $\mathbf{F}$ & $\%$ & $\mathbf{F}$ & $\%$ & \\
\hline \multicolumn{12}{|l|}{ Kualitas Pelayanan (X) } \\
\hline \multicolumn{12}{|l|}{ Tangibles (X1) } \\
\hline $\mathrm{X} 1.1$ & 0 & 0 & 0 & 0 & 33 & 35.5 & 54 & 58.1 & 6 & 6.5 & 3.71 \\
\hline $\mathrm{X} 1.2$ & 0 & 0 & 0 & 0 & 41 & 44.1 & 51 & 54.8 & 1 & 1.1 & 3.57 \\
\hline $\mathrm{X} 1.3$ & 0 & 0 & 0 & 0 & 52 & 55.9 & 41 & 44.1 & 0 & 0 & 3.44 \\
\hline $\mathrm{X} 1.4$ & 0 & 0 & 0 & 0 & 12 & 12.9 & 81 & 87.1 & 0 & 0 & 3.87 \\
\hline $\mathrm{X} 1.5$ & 0 & 0 & 0 & 0 & 17 & 18.3 & 66 & 71.0 & 10 & 10.8 & 3.92 \\
\hline \multicolumn{12}{|l|}{ Reability (X2) } \\
\hline $\mathrm{X} 2.1$ & 0 & 0 & 23 & 24. & 38 & 40.9 & 32 & 34.4 & 0 & 0 & 3.10 \\
\hline $\mathrm{X} 2.2$ & 0 & 0 & 17 & 18. & 38 & 40.9 & 37 & 38.9 & 1 & 1.1 & 3.24 \\
\hline $\mathrm{X} 2.3$ & 0 & 0 & 0 & 0 & 29 & 31.2 & 61 & 65.6 & 3 & 3.2 & 3.72 \\
\hline \multicolumn{12}{|l|}{ Responsiveness (X3) } \\
\hline X3.1 & 0 & 0 & 0 & 0 & 54 & 58.1 & 33 & 35.5 & 6 & 6.5 & 3.48 \\
\hline $\mathrm{X} 3.2$ & 0 & 0 & 0 & 0 & 46 & 49.5 & 47 & 50.5 & 0 & 0 & 3.51 \\
\hline $\mathrm{X} 3.3$ & 0 & 0 & 0 & 0 & 19 & 20.4 & 63 & 67.7 & 11 & 11.8 & 3.91 \\
\hline X3.4 & 0 & 0 & 0 & 0 & 18 & 19.4 & 74 & 79.6 & 1 & 1.1 & 3.82 \\
\hline \multicolumn{12}{|l|}{ Assurance (X4) } \\
\hline $\mathrm{X} 4.1$ & 0 & 0 & 0 & 0 & 18 & 19.4 & 74 & 79.6 & 1 & 1.1 & 3.87 \\
\hline $\mathrm{X} 4.2$ & 0 & 0 & 0 & 0 & 23 & 24.7 & 70 & 75.3 & 0 & 0 & 3.75 \\
\hline $\mathrm{X} 4.3$ & 0 & 0 & 11 & 11. & 65 & 69.9 & 16 & 17.2 & 1 & 1.1 & 3.09 \\
\hline $\mathrm{X} 4.4$ & 0 & 0 & 5 & 5.4 & 53 & 57.0 & 35 & 37.6 & 0 & 0 & 3.32 \\
\hline \multicolumn{12}{|l|}{ Emphaty (X5) } \\
\hline $\mathrm{X} 5.1$ & 0 & 0 & 0 & 0 & 22 & 23.7 & 71 & 76.3 & 0 & 0 & 3.76 \\
\hline $\mathrm{X} 5.2$ & 0 & 0 & 1 & 1.1 & 27 & 29.0 & 61 & 65.6 & 4 & 4.3 & 3.73 \\
\hline $\mathrm{X} 5.3$ & 0 & 0 & 0 & 0 & 13 & 14.0 & 63 & 67.7 & 17 & 18.3 & 4.04 \\
\hline \multicolumn{12}{|l|}{ Kepuasan Pelanggan (Y) } \\
\hline Y.1 & 0 & 0 & 9 & 9.7 & 56 & 60.2 & 28 & 30.1 & 0 & 0 & 3.20 \\
\hline Y.2 & 0 & 0 & 0 & 0 & 27 & 29.0 & 54 & 58.1 & 12 & 12.9 & 3.84 \\
\hline Y.3 & 0 & 0 & 0 & 0 & 5 & 5.4 & 76 & 81.7 & 12 & 12.9 & 4.08 \\
\hline Y.4 & 0 & 0 & 0 & 0 & 5 & 5.4 & 74 & 79.6 & 14 & 15.1 & 4.10 \\
\hline Y.5 & 0 & 0 & 0 & 0 & 17 & 18.3 & 62 & 66.7 & 14 & 15.1 & 3.97 \\
\hline
\end{tabular}




\begin{tabular}{|l|l|l|l|l|l|l|l|l|l|l|l|}
\hline Loyalitas Pelanggan $(\mathrm{Z})$ & & & & & & & & & & & \\
\hline Z.1 & 0 & 0 & 0 & 0 & 6 & 6.5 & 76 & 81.7 & 11 & 11.8 & 4.05 \\
\hline Z.2 & 0 & 0 & 0 & 0 & 4 & 4.3 & 85 & 91.4 & 4 & 4.3 & 4.00 \\
\hline Z.3 & 0 & 0 & 19 & 20 & 67 & 72.0 & 7 & 7.5 & 0 & 0 & 2.87 \\
\hline Z.4 & 0 & 0 & 4 & 4.3 & 58 & 62.4 & 31 & 33.3 & 0 & 0 & 3.29 \\
\hline Z.5 & 0 & 0 & 0 & 0 & 20 & 21.5 & 60 & 64.5 & 13 & 14.0 & 3.92 \\
\hline Z.6 & 0 & 0 & 5 & 5. & 27 & 29.0 & 61 & 65.6 & 0 & 0 & 3.60 \\
\hline
\end{tabular}

Sumber: Data diolah

Berdasarkan tabel di atas, indikator-indikator pada tiap dimensi tangibles, reability, responsiveness, emphaty dan assurance) pada variabel kualitas pelayanan mempunyai nilai means diatas 3 dan dibawah 4 berarti mempunyai kecenderungan respon yang negative. Hal ini menunjukan bahwa kualitas pelayanan yang diukur oleh TERRA belum optimal dan masih dirasakan belum puas. Nilai rata- rata pada dimensi tangible adalah 3.44 untuk pertanyaan X1.3 yaitu penampilan karyawan yang dirasa kurang rapi, Nilai rata-rata pada dimensi reliability adalah 3.10 untuk pertanyaan X2.1 yaitu ketepatan waktu yang kurang sesuai dengan estimasi saat diinfokan di awal, Nilai rata-rata pada dimensi responsiveness adalah 3.48 untuk pertanyaan X3.1 yaitu Ketanggapan karyawan terhadap permasalahan pelanggan dirasa kurang memuaskan, Nilai rata-rata pada dimensi assurance adalah 3.09 untuk pertanyaan X4.3 yaitu kemampuan dan pengetahuan karyawan yang dirasa kurang memuaskan, Nilai rata-rata pada dimensi emphaty adalah 3.73 untuk pertanyaan X5.2 yaitu kemudahan dalam bertransaksi dirasa kurang memuaskan. Nilai rata- rata pada variable kepuasan pelanggan adalah 3.20 untuk pertanyaan Y.1 yaitu kesesuaian kualitas terhadap ekspektasi dari pelanggan yang dirasa kurang memuaskan. Nilai rata-rata pada dimensi loyalitas pelanggan adalah 2.87 untuk pertanyaan Z.3 yaitu pelanggan tidak merekomendasikan kepada orang lain untuk melakukan service di Indovisual service solution.

Terdapat indikator diatas 4 yang menunjukan kecenderungan respon yang positif yaitu pada variable kepuasan pelanggan dengan nilai rata-rata 4.10 untuk pertanyaan Y.4 yaitu Indovisual Service Solution merupakanpilihan pertama pelanggan jika ingin melakukan service projector, dan pada variable loyalitas pelanggan dengan nilai rata-rata 4.05 pada pertanyaan Z.1 yaitu pelanggan akan menjadikan Indovisual Sevice solution sebagai pilihan utama dalam menggunakan jasa service

\section{Uji Validitas}

Berikut ini adalah hasil output factor loading konstruk kualitas pelayanan, kepuasan pelanggan dan loyalitas pelanggan pada PLS : 


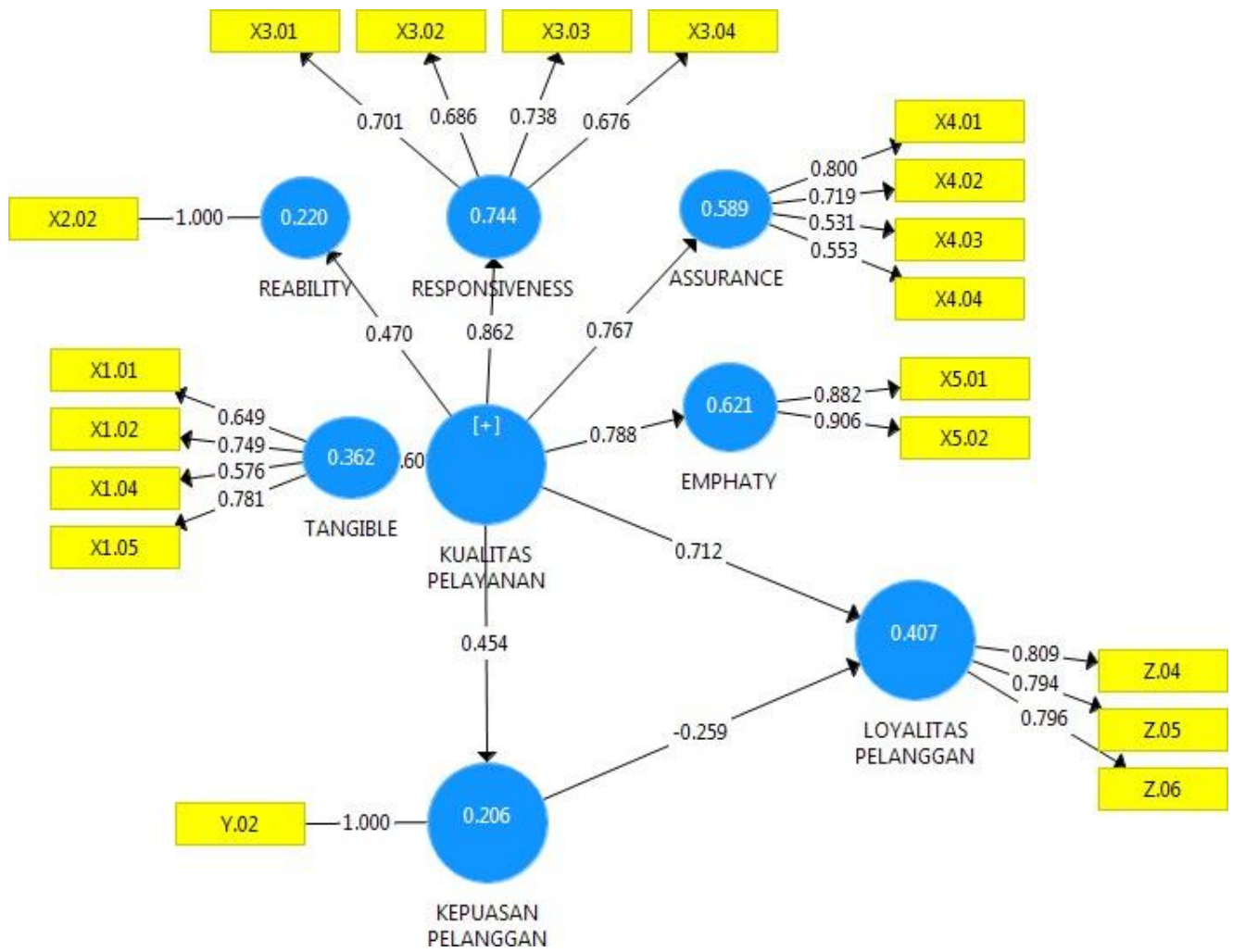

Gambar 3. Loading Factor Variabel Penelitian

Sumber : Hasil diolah Smart PLS 3.0

Berdasarkan output pada diagram jalur di atas, factor loading untuk second order sudah memenuhi convergent validity yaitu nilai indikatornya sudah di atas 0,5 .

\section{Pengujian Reliabilitas}

Dalam penelitian, suatu variabel dikatakan cukup reliabilitas bila variabel tersebut mempunyai nilai construct reliability lebih besar dari 0,6 . Berikut ini adalah tabel hasil pengujian reliabilitas pada masing-masing dimensi pada variabel laten kualitas pelayanan, kepuasan nasabah dan brand image.

Tabel 4. Pengujian Reliabilitas

\begin{tabular}{|l|r|r|c|}
\hline Variabel \& Dimensi & AVE & Composite Reability & Cronbachs Alpha \\
\hline KUALITAS PELAYAN $(\mathbf{X})$ & 0.237 & 0.803 & 0.745 \\
\hline TANGIBLES & 0.481 & 0.785 & 0.645 \\
\hline RELIABILITY & 1.000 & 1.000 & 1.000 \\
\hline RESPONSIVNESS & 0.491 & 0.794 & 0.657 \\
\hline ASSURANCE & 0.436 & 0.750 & 0.558 \\
\hline EMPHATY & 0.800 & 0.889 & 0.750 \\
\hline KEPUASAN PELANGGAN $(\mathbf{Y})$ & 1.000 & 1.000 & 1.000 \\
\hline LOYALITAS PELANGGAN $(Z)$ & 0.639 & 0.842 & 0.718 \\
\hline
\end{tabular}

Sumber : Hasil diolah Smart PLS 3.0 
Berdasarkan hasil output reliabilitas diatas, dapat disimpulkan bahwa untuk semua dimensi dalam variabel kualitas pelayanan, kepuasan nasabah dan brand image memiliki composite reliability di atas 0,7 sehingga dapat disimpulkan bahwa indikator- indikator yang digunakan pada masing-masing dimensi mempunyai reabilitas yang cukup baik atau mampu untuk mengukur konstruknya.

Berdasarkan hasil analisis validitas dan reliabilitas di atas, pengaruh second order konstruk kualitas pelayanan, kepuasan nasabah dan brand image berpengaruh terhadap dimensi first order konstruk tangibles, reability, responsiveness, emphaty, assurance, kualitas, pelayanan nasabah, nilai, strength, uniqueness dan favourable dengan nilai Tstatistik di atas 1,660. Sehingga dapat disimpulkan bahwa konstruk kualitas pelayanan dibentuk oleh lima dimensi yaitu tangibles, reability, responsiveness, emphaty dan assurance. Konstruk kepuasan nasabah dibentuk oleh tiga dimensi yaitu kualitas, pelayanan nasabah dan nilai. Konstruk brand image dibentuk oleh dua dimensi yaitu strength, uniqueness dan favourable.

\section{Evaluasi Goodness Of Fit Model Stuktural (Inner Model)}

Evaluasi goodness of fit model struktural diukur dengan menggunakan nilai predivtiverelevance $\left(\mathrm{Q}^{2}\right)$. Nilai predictive- relevance $\left(\mathrm{Q}^{2}\right)$ dihitung dengan menggunakan rumus sebagai berikut :

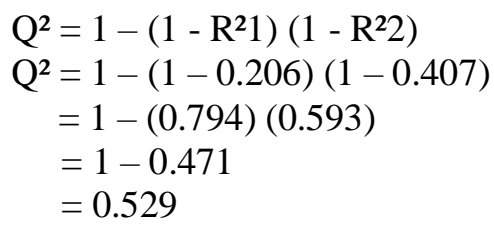

Dimana $\mathrm{R}^{2} 1$ dan $\mathrm{R}^{2} 2$ merupakan $R$ Square variabel endogen dalam model. Interprestasi $\mathrm{Q}^{2}$ sama dengan koefisien determinasi total pada analisis jalur (mirip dengan $\mathrm{R}^{2}$ pada regresi). $\mathrm{R}^{2}$ adalah koefisien determinasi yang merupakan bagian dari variasi total dalam variabel dependen yang dijelaskan oleh variasi dalam variabel independen. Tabel 4 berikut ini menjelaskan hasil analisis koefisien determinasi dari variabel- variabel penelitian:

Tabel 5. $R$ Square

\begin{tabular}{|c|c|}
\hline Variabel & R Square \\
\hline Kepuasan Pelanggan $(\mathrm{Y})$ & 0.206 \\
\hline Loyalitas Pelanggan $(\mathrm{Z})$ & 0.407 \\
\hline Predictive-Relevance $\left(\mathrm{Q}^{2}\right)$ & 0.529 \\
\hline
\end{tabular}



Berdasarkan koefisien determinasi pada tabel diatas, diperoleh nilai $\mathrm{R}^{2}$ untuk variabel Kepuasan Pelanggan sebesar 0.20 yang artinya nilai tersebut mengindikasikan bahwa variabel Kepuasan Nasahah dapat dijelaskan oleh variabel Kualitas Pelayanan sebesar 20\% sedangkan sissanya yaitu sebesar $80 \%$ dipengaruhi oleh variabel lain yang tidak terdapat dalam model penelitian. Nilai $\mathrm{R}^{2}$ untuk variabel Loyalitas Pelanggan sebesar 0.407 yang artinya bahwa variabel Loyalitas Pelanggan dijelaskan oleh variabel Kualitas Pelayanan sebesar $40 \%$ sedangkan sisanya yaitu sebesar $60 \%$ dipengaruhi oleh variabel lain yang tidak terdapat dalam model penelitian. Evaluasi inner model yang tersebut cukup baik djalam menjelaskan variabel Kepuasan Pelanggan dan Loyalitas Pelanggan. Sedangkan nilai predictive-relevance untuk model struktural dalam penelitian ini adalah sebesar 0.52 atau $52 \%$ artinya model mampu menjelaskan fenomena Loyalitas Pelanggan dikaitkan dengan beberapa variabel, yaitu Kepuasan Pelanggan. Oleh karena itu model dapat dikatakan baik, atau model memiliki nilai prediktif yang baik. Pada akhirnya model dapat digunakan untuk pengujian hipotesis.

\section{Pengujian Hipotesis}

Untuk menguji hipotesis dalam penelitian ini, digunakan nilai tstatistik pada masing-masing jalur pengaruh langsung secara parsial. Berikut ini adalah gambar yang menjelaskan diagram jalur untuk pengujian hipotesis :

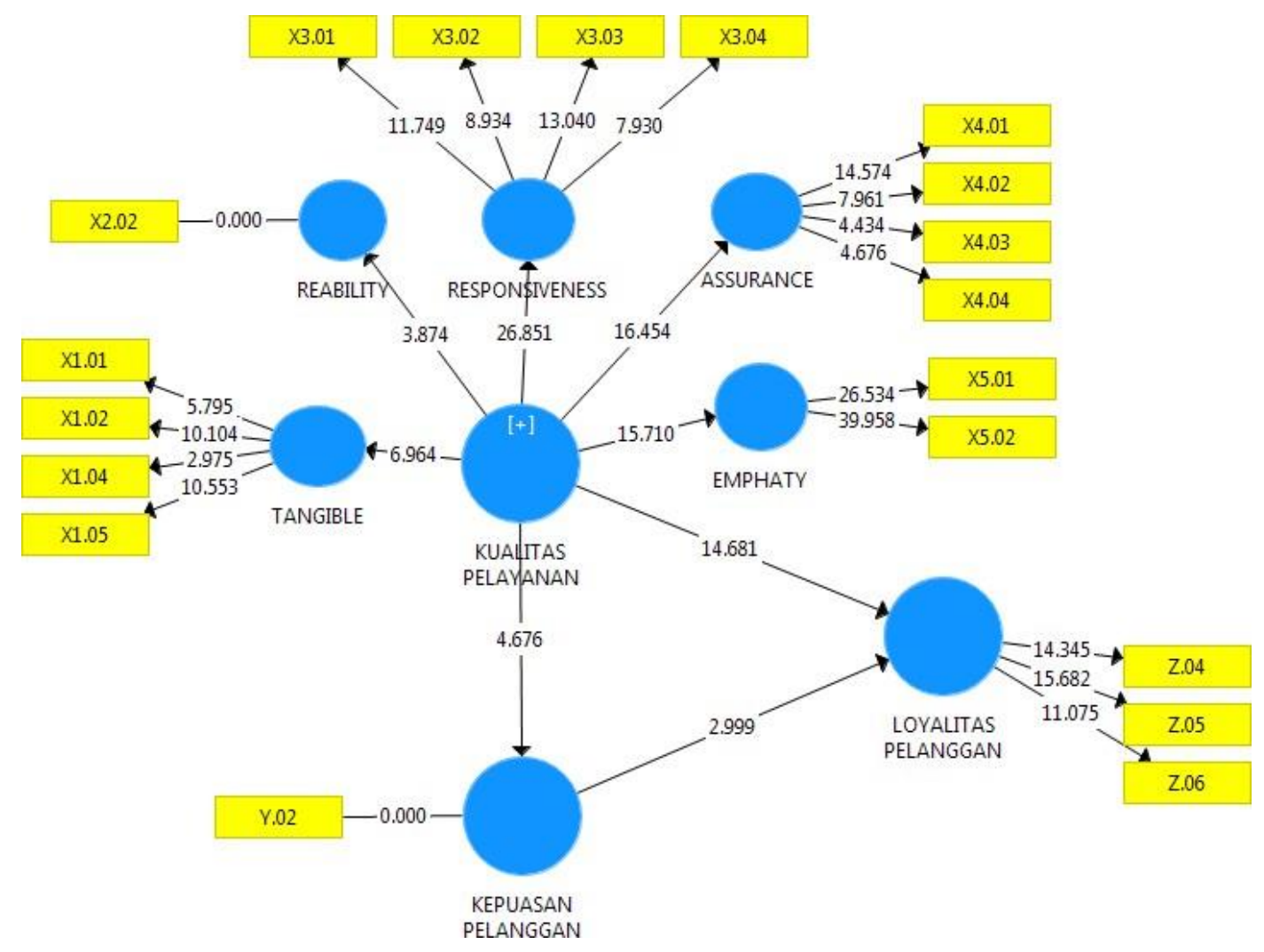

Gambar 4. Output Diagram Path Penelitian

Sumber : Hasil diolah Smart PLS 3.0 
Berdasarkan diagram path pengujian hipotesis di atas, semua dimensi pada masing-masing variabel mempunyai nilai $\mathrm{T}_{\text {statistics }}$ lebih besar dari 1,660 sehingga dimensi-dimensi tersebut mampu mengukur setiap konstruknya. Sedangkan untuk menguji hubungan antar variabel (uji hipotesis), maka digunakan nilai tstatistik dari output Smart PLS yang dibandingkan dengan nilai $\mathrm{T}_{\text {tabel. }}$. Berikut ini adalah tabel yang memberikan hasil hubungan antar konstruk (variabel).

Tabel 6. Path Coefficients (Mean, STDEV, T-Values)

\begin{tabular}{|l|l|l|l|l|}
\hline Hubungan Antar Variabel & $\begin{array}{l}\text { Koefisien } \\
\text { Parameter }\end{array}$ & T Statistic & P Value & Keterangan \\
\hline Kualitas pelayanan -> Tangible & 0.601 & 6.694 & 0.000 & Signifikan** \\
\hline Kualitas pelayanan -> Reability & 0.470 & 3.874 & 0.000 & Signifikan** \\
\hline Kualitas pelayanan -> Responsiveness & 0.862 & 26.851 & 0.000 & Signifikan** \\
\hline Kualitas pelayanan -> Assurance & 0.767 & 16.454 & 0.000 & Signifikan** \\
\hline $\begin{array}{l}\text { Kualitas pelayanan -> Emphaty } \\
\text { Kualitas Pelayanan -> } \\
\text { Kepuasan Pelanggan }\end{array}$ & 0.788 & 15.710 & 0.000 & Signifikan** \\
\hline $\begin{array}{l}\text { Kepuasan Pelanggan -> } \\
\text { Loyalitas Pelanggan }\end{array}$ & -0.454 & 4.676 & 0.000 & Signifikan** \\
\hline $\begin{array}{l}\text { Kualitas Pelayanan ->Loyalitas } \\
\text { Pelanggan }\end{array}$ & 0.712 & 14.681 & 0.000 & Signifikan** \\
\hline $\begin{array}{l}\text { Kualitas Pelayanan -> } \\
\text { Kepuasan Pelanggan -> } \\
\text { Loyalitas Pelanggan }\end{array}$ & 0.769 & 15.534 & 0.000 & Signifikan** \\
\hline
\end{tabular}

Ket: ** Signifikan pada level 5\%, * Signifikan pada level 10\%

Sumber : Hasil diolah Smart PLS 3.0

Berdasarkan diagram jalur penelitian di atas, kemudian diterjemahkan ke dalam bentuk persamaan sebagai berikut :

$$
\begin{aligned}
& \mathrm{KPG}=\mathrm{a}+\mathrm{b} 0,454+\mathrm{e}_{1} \ldots \ldots \ldots \ldots \ldots .(3.1) \\
& \mathrm{LP}=\mathrm{a}+\mathrm{b}_{1}-0,259+\mathrm{b}_{2} 0,712+\mathrm{b}_{4} 0,769 \mathrm{e}_{2}
\end{aligned}
$$

Pada model penelitian pertama, pengaruh kualitas pelayanan terhadap kepuasan nasabah mempunyai nilai koefisien regresi sebesar 0,454 artinya ketika kualitas pelayanan meningkat (bertambah 1) maka kepuasan nasabah akan naik sebesar 0,454. Begitu juga sebaliknya, jika kualitas pelayanan menurun (berkurang) maka kepuasan nasabah pun akan menurun.

Pada model penelitian kedua, kepuasan pelanggan tidak ada pengaruhnya jika dibandingkan dengan kualitas pelayanan, dengan koefisien regresi sebesar - 0,259 sedangkan kualitas pelayanan terhadap loyalitas pelanggan berpengaruh sangat besar 0.712 . Artinya ketika kualitas pelayanan meningkat (bertambah) maka loyalitas pelanggan juga meningkat. 


\section{Pengaruh kualitas pelayanan terhadap kepuasan pelanggan}

Berdasarkan uji hipotesis Koefisien parameter jalur yang diperoleh dari pengaruh variabel kualitas pelayanan terhadap kepuasan pelanggan adalah sebesar 0.454 dengan nilaiTstatistik $4.676>1.660$ pada taraf signifikansi $\alpha=0.05(5 \%)$ yang menyatakan bahwa terdapat pengaruh positif dan signifikan antara kualitas pelayanan terhadap kepuasan pelanggan. Nilai 0.754 pada koefisien parameter artinya adalah semakin baik kualitas pelayanan maka kepuasan pelanggan akan semakin baik. Pengaruh kualitas pelayanan terhadap dimensi kepuasan pelanggan yaitu tangibles, reability, responsiveness, emphaty dan assurance juga berpengaruh positif dan signifikan. Hasil penelitian ini mendukung hipotesis yang pertama, dimana terdapat pengaruh positif dan signifikan antara kualitas pelayanan terhadap kepuasan pelanggan

Hal ini sejalan dengan penelitian yang di dokumentasikan oleh Nandhasari (2015), Atsalada (2012), Safitri (2014), Normasari (2013), Mayasari (2013), Harun (2006), Ramadhan (2013), Yuliarmi, Riyasa (2007), Sinaga (2010).Dengan adanya kualitas pelayanan yang baik dapat menumbuhkan rasa kepuasan nasabah terhadap perusahaan.

\section{Pengaruh kualitas pelayanan terhadap loyalitas pelanggan}

Berdasarkan hasil uji hipotesis Koefisien parameter jalur yang diperoleh dari pengaruh variabel kualitas pelayanan terhadap loyalitas Pelanggan adalah sebesar 0.712 dengan nilai Tstatistik $14.681>1.660$ pada taraf signifikansi $\alpha=0.05$ (5\%) yang menyatakan bahwa terdapat pengaruh signifikan antara kualitas pelayanan terhadap loyalitas pelanggan. Nilai 0.712 pada koefisien parameter artinya adalah semakin tinggi kualitas pelayanan maka brand imageakan semakin baik. Hasil penelitian ini mendukung hipotesis yang kedua, dimana terdapat pengaruh positif dan signifikan antara kualitas pelayanan terhadap loyalitas pelanggan. Hasil ini menunjukkan bahwa dengan meningkatkan kualitas pelayanan maka pelanggan akan merasa loyal dengan pelayanan yang diberikan.

Hal ini sejalan dengan penelitian yang di dokumentasikan oleh Nandhasari (2015), Dengan adanya kualitas pelayanan yang baik dapat menumbuhkan loyalitas terhadap perusahaan.

\section{Pengaruh Kepuasan Pelanggan Terhadap Loyalitas Pelanggan}

Berdasarkan hasil uji hipotesis, Koefisien parameter jalur yang diperoleh dari pengaruh variabel kepuasan pelanggan terhadap loyalitas pelanggana dalah sebesar -0.259 dengan nilai Tstatistik $2.999>1.660$ pada taraf signifikansi $\alpha=0.05$ (5\%) yang menyatakan bahwa tidak terdapat pengaruh positif signifikan antara kepuasan pelanggan terhadap loyalitas pelanggan. pada koefisien parameter - 0.259 artinya ini menunjukkan kondisi yang berarti semakin tinggi kepuasan pelanggan bukan berarti tidak berhubungan tetapi tidak selalu meningkatkan loyalitas nasabah. Sehingga hipotesis penelitian ketiga ditolak, bahwa tidak terdapat pengaruh positif signifikan kepuasan pelanggan terhadap loyalitas pelanggan. Hal ini disebabkan karena beberapa hal antara lain adalah harga yang cukup tinggi dibanding dengan service center lainnya, strategi marketing yang kurang baik, respon yang lamban terhadap kebutuhan pelanggan, dan juga estimasi indent barang yang cukup lama yang mengakibatkan menurunnya loyalitas pelanggan.

Hal ini sejalan dengan penelitian yang di dokumentasikan oleh Sinaga (2010) Hasil analisis jalur dalam pengujian antara kepuasan pelanggan terhadap loyalitas pelanggan menunjukkan koefisien yang negatif. Sedangkan uji secara individual diperoleh nilai CR -0,719 dengan nilai signifikansi 0,472 . Karena nilai signifikansi lebih besar dari 0,05 dan nilai CR $(-0,719)$ lebih kecil dari t tabel $(1,96)$ maka hipotesis ditolak. 


\section{Pengaruh kualitas pelayanan terhadap kepuasan pelanggan dan loyalitas pelanggan}

Berdasarkan hasil hipotesis, Nilai $\mathrm{P}$ Value variabel kualitas pelayanan terhadap kepuasan pelanggan dan loyalitas pelanggan adalah 0.000 dengan nilai Tstatistik $15.534>3,115$ pada taraf signifikansi $\alpha=0,05(5 \%)$ menyatakan bahwa terdapat pengaruh positif dan signifikan kualitas pelayanan terhadap kepuasan pelanggan dan loyalitas Pelanggan. Hasil ini mendukung hipotesis penelitian keempat, dimana terdapat pengaruh positif dan signifikan antara kualitas pelayanan terhadap kepuasan pelanggan dan loyalitas pelanggan. Artinya adalah semakin baik kualitas pelayanan terhadap kepuasan pelanggan maka loyalitas pelanggan juga akan semakin baik. Hal ini sejalan dengan penelitian yang dilakukan Safitri (2014),

Dalam memelihara situasi yang kondusif di dalam perusahaan, penerapan kualitas pelayanan haruslah dijalankan dengan baik oleh para pegawai perusahaan. Kualitas pelayanan yang baik akan membuat suatu rasa kepuasan yang dirasakan pelanggan. Rasa kepuasan tersebut akan menjadikan Loyalitas pelanggan menjadi sangat baik, jika Kepuasan pelanggan meningkat, maka pelanggan akan menggunakan kembali pelayanan yang disediakan perusahaan.

\section{PENUTUP}

Berdasarkan hasil penelitian secara empiris Kualitas pelayanan berpengaruh positif dan signifikan terhadap kepuasan pelanggan. Hasil ini menunjukkan bahwa dengan meningkatkan kualitas pelayanan maka pelanggan akan merasa puas dengan pelayanan yang diberikan. Kualitas Pelayanan berpengaruh positif dan signifikan terhadap loyalitas Pelanggan. Hasil ini menunjukkan bahwa dengan meningkatkan kualitas pelayanan maka pelanggan akan merasa loyal dan akan terus menggunakan jasa PT Indovisual Service Solution Kepuasan pelanggan tidak berpengaruh positif signifikan terhadap loyalitas pelanggan. Artinya adalah semakin rendah kepuasan pelanggan maka loyalitas pelanggan juga akan semakin menurun Kualitas Pelayanan berpengaruh positif dan signifikan terhadap loyalitas Pelanggan. Hasil ini menunjukkan bahwa dengan meningkatkan kualitas pelayanan maka pelanggan akan merasa loyal dan akan terus menggunakan jasa PT Indovisual Service Solution.

Keterbatan penelitian ini adalah tidak menggunakan teknik wawancara sehingga pengumpulan data hanya berdasarkan hasil yang telah terkumpul berdasarkan kuesioner yang telah disebar kepada responden yaitu customer PT Indovisual Service Solution dan ketidaksesuaian hasil pengujian lapangan dengan hipotesis ke 3 dimana kepuasan pelanggan tidak berpengaruh positif signifikan terhadap loyalitas pelanggan.

Penulis memberi saran pada PT Indovisual Service Solution yaitu Perbaikan terhadap dimensi daya tanggap dapat dimulai dengan memberikan pelatihan kepada customer service yang setiap hari bertatap muka dan berinteraksi dengan para pelanggan. Customer service harus memiliki kemampuan melayani pelanggan secara cepat dan tepat. Selain itu, semua staf PT Indovisual Service Solution harus memiliki kemampuan dalam berkomunikasi, sopan santun, cekatan, dan bertanggung jawab penuh terhadap pelanggannya. Semua hal itu dapat dimulai dengan memberikan pelatihan secara rutin kepada seluruh staf mengenai Standard Operating Procedure (SOP) serta mengikuti seminar dan pelatihan yang berkaitan dengan kualitas pelayanan. Secara umum pelanggan menginginkan pelayanan yang berkualitas, karena hal-hal yang berkaitan atau yang dapat meningkatkan kualitas pelayanan khususnya dimensi daya tanggap perlu lebih diperhatikan

PT Indovisual Service Solution harus berusaha untuk dapat memperbaiki pelayanan agar pelanggan merasa puas, dan meningkatkan minat loyalitas pelanggan terhadap PT indovisual Service Solution. Cara yang dapat ditempuh adalah dengan meningkatkan penanganan keluhan pada pelanggan dan dengan menggelar acara khusus (special event), seperti pertemuan dengan nasabah yang memiliki kontribusi cukup besar terhadap perusahaan. Melalui 
pertemuan tersebut PT Indovisual Service Solution dapat lebih dekat dan lebih mudah memahami keinginan para nasabah sehingga dapat meningkatkan kepuasan yang nantinya diharapkan dapat berdampak positif terhadap terbentuknnya loyalitas. Karena ketidaksesuaian hasil pengujian lapangan dengan hipotesis ke 3 dimana kepuasan pelanggan tidak berpengaruh positif signifikan terhadap loyalitas pelanggan, maka untuk penelitian selanjutnya diharapkan untuk menambahkan variable independent seperti harga atau merek dll

\section{REFERENSI}

Armstrong, T. (2009). Multiple intelligences in the classroom. Cloverdale, CA: ASCD Publications.

Asghar Afshar Jahanshahi,dkk. 2011."Study the Effects of Customer Service and Product Quality on Customer Satisfaction and Loyalty".International Journal of Humanities and Social Science. Vol. 1 No.7

Alotaibi, G. A. (2001). Antecedents of Organizational Citizenship Behavior: A Study of Public Personal in Kuwait. Public Personal Management 3, 30, 363.

Achmad, Safitri Lia \& Lailatul Amanah. (2014). Jurnal Ilmu Riset \& Akuntansi. Pengaruh Keputusan Investasi, Keputusan Pendanaan, Kebijakan Dividend an Kinerja Keuangan terhadap Nilai Perusahaan. 3(9), 1-15.

Asfaw M, Wondaferash M, Taha M, Dube L (2015). Prevalence of undernutrition and associated factors among children aged between six to fifty nine months in Bule Hora district, south ethiopia. BMC Public Health, 15(1):41-46.

Atsalada, Nanda. 2012. Analisis Pengaruh Kualitas Pelayanan Terhadap Kepuasan Konsumen dan Dampaknya Pada Loyalitas Konsumen Dalam Menggunakan Jasa Transportasi PO Sumber Alam. Skripsi. Semarang: UNDIP.

Hasan, Ali. 2014. Marketing dan Kasus-Kasus Pilihan. Jakarta: CAPS

Hafeez, Samraz \& Muhammad, Bakhtiar. (2012). The Impact of Service Quality, Customer Satisfaction and Loyalty Programs on Customer's Loyalty: Evidence from Banking Sector of Pakistan, Vol.3, No.16, 200-209. Dipublikasikan di http://ijbssnet.com/journals/Vol_3_No_16_Special_Issue_August_2012/21. pdf, diakses pada 6 Desember 2013.

Indrawan, R. \& Yaniawati R.P. (2016). Metodologi Penelitian Kuantitatif.. Kualitatif, dan Campuran Untuk Manajemen, Refika Aditama: Bandung.

Kotler, Philip Dan Kevin Lane Keller. 2009. Manajemen Pemasaran. Edisi 13 Jilid satu. Erlangga : Jakarta

Kotler, Philip \& Keller, Kevin Lane. 2009. Manajemen Pemasaran. Edisi 13 Jilid Dua. Erlangga : Jakarta.

Lupiyoadi, Rambat, (2013). Manajemen Pemasaran Jasa. Berbasis kompetensi. Salemba Empat: Jakarta.

Mayasari, D., 2013. Penerapan Metode Pembelajaran PQ4R dalam Meningkatkan Hasil Belajar Siswa (Penelitian Tindakan Kelas Di SMPN 3 Tanggerang Selatan). Skripsi Jurusan Ilmu Pengetahuan Sosial UIN Syarif Hidayatullah Jakarta. Diakses 10 Februari 2016.

Normasari, Selvy, Srikandi Kumadji, Andriani Kusumawati. 2013. Pengaruh Kualitas Pelayanan terhadap Kepuasan Pelanggan, Citra Perusahaan dan Loyalitas Pelanggan, Jurnal Administrasi Bisnis (JAB), 6 (2).

Nandhasari. 2015. Analisis Faktor-Faktor Yang Mempengaruhi Kepuasan Konsumen Dan Implikasinya Terhadap Minat Loyalitas. Skripsi.Semarang: Fakultas Ekonomi dan Bisnis Universitas Diponegoro. 
Nandhasari. 2015. Analisis Faktor-Faktor yang Mempengaruhi Kepuasan Konsumen dan Implikasinya Terhadap Minat Loyalitas. Skripsi FEB Universitas Diponegoro Semarang.

Palilati, Alida (2007). Pengaruh Nilai Pelanggan, Kepuasan terhadap Loyalitas.

Nasabah Tabungan Perbankan di Sulawesi Selatan, Universitas. Kristen Petra: Sulawesi

Ramadhan, Rahmat. 2013. Persepsi Mahasiswa Terhadap Penggunaan Poduk Smartphone Blackberry (Studi Kasus Pada Mahasiswa Politeknik Negeri Jurusan Teknik Kimia). Jurusan Administrasi Bisnis Polsri. Laporan Akhir (Tidak di Publikasikan): Polsri.

Sinaga. Hardian Hariono. 2010. Analisis Pengaruh Total Arus Kas, Komponen Arus Kas, Laba Akuntansi Terhadap Return Saham.

Sugiyono. (2011). Metode Penelitian Kuantitatif, Kualitatif dan R\&D. Afabeta. :Bandung

Tjiptono, Fandy (2009). Strategi Pemasaran, Edisi Kedua, Cetakan Ketujuh, Andi: Yogyakarta

Yazid, (2008). Pemasaran Jasa, Konsep dan Implementasi, Edisi Kedua. EKONISIA: Yogyakarta.

Yuliarmi, Ni Nyoman dan Putu Riyasa. 2007. Analisis Faktor-Faktor Yang Mempengaruhi Kepuasan Pelanggan Terhadap Pelayanan PDAM Kota Denpasar. Denpasar: Buletin Studi Ekonomi Volume 12 Nomor 1 Tahun 2007.

Wati, L.N. (2017). Metodologi Penelitian Bisnis Terapan, Aplikasi SPSS, EVIEWS, Smart PLS, dan AMOS. Percetakan Mujahid: Bandung 